\title{
Determination of physical $\left(k_{\mathrm{q}}\right)$ and chemical $\left(k_{\mathrm{r}}\right)$ rate constants for singlet oxygen quenching using the thermolysis of a naphthalenic endoperoxide in $\mathrm{H}_{2} \mathrm{O}$ and $\mathrm{D}_{2} \mathrm{O}$
}

\author{
Christel Pierlot $^{\mathrm{a}}$, Véronique Nardello ${ }^{\mathrm{a}}$, Reinhard Schmidt ${ }^{\mathrm{b}}$, and Jean-Marie Aubry ${ }^{\mathrm{a}^{*}}$ \\ ${ }^{a}$ LCOM Equipe « Oxydation et Formulation », UMR CNRS 8009, ENSCL, BP 90108, \\ F-59652 Villeneuve d'Ascq Cedex, France \\ ${ }^{b}$ Institute für Physikalische und Theoretische Chemie, J. W. Goethe-Universität, Max-von-Laue- \\ Strasse 7, D-60438 Frankfurt am Main, Germany \\ E-mail: jean-marie.aubry@univ-lille1.fr
}

This article is dedicated to Prof. Waldemar Adam in honor of his $\mathbf{7 0}^{\text {th }}$ birthday

\begin{abstract}
A chemical source of singlet oxygen $\left({ }^{1} \mathrm{O}_{2}: \mathrm{O}_{2}\left({ }^{1} \Delta_{\mathrm{g}}\right)\right)$, based on thermolysis of the water-soluble naphthalenic endoperoxide $\mathrm{NDPO}_{2}$ is used to determine both the overall $\left(k_{\mathrm{r}}+k_{\mathrm{q}}\right)$ and the chemical $\left(k_{\mathrm{r}}\right)$ quenching rate constants of water-soluble substrates. Unlike current photochemical techniques, this chemical method is particularly suitable for sensitive and/or colored substrates, which can react directly with photosensitizers in their excited states or absorb incident light. This simple method has been applied to assess the reactivity of five organic compounds towards ${ }^{1} \mathrm{O}_{2}$. The first one (carminic acid) is a foodstuff coloring agent (C.I. Natural Red 4). The four other ones (methyl gallate, caffeic acid, trimethylhydroquinone, trolox) are well-known phenolic antioxidants. All of them exhibit high overall rate constants $\left(10^{7} \mathrm{M}^{-1} \mathrm{~s}^{-1}<\left(k_{\mathrm{r}}+k_{\mathrm{q}}\right)<10^{9} \mathrm{M}^{-1} \mathrm{~s}^{-1}\right)$ and varying range of chemical quenching $\left(0.1<k_{\mathrm{r}} /\left(k_{\mathrm{r}}+k_{\mathrm{q}}\right) \leq 1\right)$. The limits of the method are also discussed in detail.
\end{abstract}

Keywords: Singlet Oxygen, naphthalenic endoperoxides, rate constants, flash photolysis, carminic acid

\section{Introduction}

Much work has been devoted to the physics, chemistry and biochemistry of singlet oxygen, $\left({ }^{1} \mathrm{O}_{2}\right.$ : $\mathrm{O}_{2}\left({ }^{1} \Delta_{\mathrm{g}}\right)$ ), since the discovery in the 1960s of its involvement in the photodynamic effect, ${ }^{1-4}$ in the photooxygenation of organic compounds ${ }^{5-6}$ and in the photodegradation of some synthetic or natural polymers. ${ }^{6-10}$ In all these processes, the scavenging of ${ }^{1} \mathrm{O}_{2}$ by compounds involves two 
pathways : physical quenching which occurs through an energy transfer with the rate constant $k_{\mathrm{q}}$ and the chemical quenching which results in the formation of oxidation products with the rate constant $k_{\mathrm{r}}{ }^{11}$ Overall rate constants $\left(k_{\mathrm{r}}+k_{\mathrm{q}}\right)$ have been determined for thousands of compounds ${ }^{12}$ since they can readily be measured either by continuous or flash photolysis ${ }^{13-22}$ or by using a standardized chemical source of ${ }^{1} \mathrm{O}_{2}$ such as naphthalenic endoperoxides. ${ }^{23-30}$ Reported values for the chemical rate constants $k_{\mathrm{r}}$ are scarcer $^{12}$ since usual methods require the precise measurement of the amount of oxidation products formed when the starting material is submitted to a given amount of ${ }^{1} \mathrm{O}_{2}$.

However, for many applications it is essential to know separately the contributions of $k_{\mathrm{r}}$ and $k_{\mathrm{q}}$. For instance, when the protective effect of additives against the photodegradation of polymers or fragrances is wanted, $k_{\mathrm{q}}$ must be maximized whereas, ideally, $k_{\mathrm{r}}$ must be negligible. On the contrary, in organic synthesis, singlet oxygenation of substrates will be feasible at a preparative level only if they significantly react with ${ }^{1} \mathrm{O}_{2}$ and, in such cases, physical quenching is undesired since it leads to a waste of available ${ }^{1} \mathrm{O}_{2}$.

Several methods have been described in the literature to determine $k_{\mathrm{r}}$. Most of them are based on the determination of the consumption rate of the substrate in the presence of calibrated sources of ${ }^{1} \mathrm{O}_{2}$. Smooth chemical generators of ${ }^{1} \mathrm{O}_{2}$ such as naphthalenic endoperoxides are particularly suitable for this purpose since upon warming they release a precise amount of ${ }^{1} \mathrm{O}_{2}$ free of any other reactive species. For instance, endoperoxide of 1,4-dimethylnaphthalene can be used in organic solvents ${ }^{23}$ whereas endoperoxides of sodium 3-(methyl-1-naphthyl)propioniate $\left(\mathrm{MNPO}_{2}\right)^{24-26}$ and of disodium 3,3'-(1,4-naphthylidene)dipropionate $\left(\mathrm{NDPO}_{2}\right)^{27-30}$ are suitable for aqueous solutions.

This paper describes a simple method for the determination of both the overall $\left(k_{\mathrm{r}}+k_{\mathrm{q}}\right)$ and the chemical $\left(k_{\mathrm{r}}\right)$ rate constants for water-soluble organic compounds using $\mathrm{NDPO}_{2}$ as a chemical generator of ${ }^{1} \mathrm{O}_{2} \cdot{ }^{29-33}$ The method, which is essentially based on the huge difference between the lifetime of ${ }^{1} \mathrm{O}_{2}$ in ordinary and deuterated water (3.1 $\mu \mathrm{s}$ vs $\left.68 \mu \mathrm{s}\right){ }^{11,12}$ is exemplified with carminic acid 1, a well-known foodstuff coloring agent (C.I. Natural red 4). This highly colored compound cannot be studied via photochemical methods because it absorbs light on a wide range of the UV-visible spectrum $(400-600 \mathrm{~nm})$ and, accordingly, it perturbs strongly the photosensitized generation of ${ }^{1} \mathrm{O}_{2}$. Four phenolic antioxidants (methyl gallate 2, caffeic acid $\mathbf{3}$, trimethylhydroquinone $\mathbf{4}$, trolox 5 ) have also been studied because they are prone to suffer side reactions, such as electron transfer, when they are submitted to photochemical sources of ${ }^{1} \mathrm{O}_{2}$.<smiles>Cc1c(C(=O)O)c(O)cc2c1C(=O)c1c(O)c([C@]3([O-])OC(CO)[C@@H](O)C(O)[C@H]3O)c(O)c(O)c1C2=O</smiles>

carminic acid, 1 
<smiles>CC(=O)c1cc(O)c(O)c(O)c1</smiles>

methyl gallate, 2<smiles>O=C(O)/C=C/c1ccc(O)c(O)c1</smiles>

caffeic acid, 3<smiles>Cc1cc(O)c(C)c(C)c1O</smiles>

trimethylhydroquinone, 4<smiles>Cc1c(C)c2c(c(C)c1O)CCC(C)(C(=O)O)O2</smiles>

trolox, 5

\section{Results and discussion}

\section{Kinetics of generation and quenching of singlet oxygen in water}

The chemical generation of ${ }^{1} \mathrm{O}_{2}$ and its different pathways of decay are presented through eqs. (1) to (4) where $k_{\mathrm{d}}$ is the pseudo-first-order constant of ${ }^{1} \mathrm{O}_{2}$ decay in the solvent, $k_{\mathrm{q}}$ and $k_{\mathrm{r}}$ are the bimolecular rate constants for the physical and the chemical quenching respectively of ${ }^{1} \mathrm{O}_{2}$ by a substrate S. ${ }^{12}$

Generation

Quenching by solvent

Physical quenching

Chemical reaction

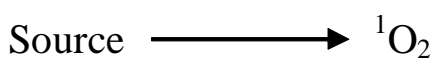

Once generated in a reaction medium (eq. 1) in the presence of a substrate $\mathrm{S},{ }^{1} \mathrm{O}_{2}$ mainly decays according to physical (eqs. 2 and 3) and chemical (eq. 4) quenching. Under pseudostationary state conditions $\left(\frac{\mathrm{d}\left[{ }^{1} \mathrm{O}_{2}\right]}{\mathrm{dt}}=0\right)$ and after integration between zero time and time $t$, we obtain the following expression (5) for the cumulative amount of generated ${ }^{1} \mathrm{O}_{2} \cdot{ }^{12}$

$$
\left[{ }^{1} \mathrm{O}_{2}\right]_{\text {cum }}=\frac{k_{\mathrm{d}}}{k_{\mathrm{r}}} \ln \frac{[\mathrm{S}]_{0}}{[\mathrm{~S}]}+\frac{\left(k_{\mathrm{r}}+k_{\mathrm{q}}\right)}{k_{\mathrm{r}}}\left([\mathrm{S}]_{0}-[\mathrm{S}]\right)
$$

The ratio $k_{\mathrm{r}} /\left(k_{\mathrm{r}}+k_{\mathrm{q}}\right)$ expresses the contribution of the chemical quenching in the overall quenching. $k_{\mathrm{d}}$, the rate constant of ${ }^{1} \mathrm{O}_{2}$ decay caused by the solvent is about 20 times larger in $\mathrm{H}_{2} \mathrm{O}\left(k_{\mathrm{d}}{ }^{\mathrm{H}_{2} \mathrm{O}}=3.2 \times 10^{5} \mathrm{~s}^{-1}\right)$ than in $\mathrm{D}_{2} \mathrm{O}\left(k_{\mathrm{d}}{ }^{\mathrm{D}_{2} \mathrm{O}}=1.5 \times 10^{4} \mathrm{~s}^{-1}\right)^{11,12}$. This strong H-D isotopic effect enables the separated determination of $k_{\mathrm{r}}$ and $k_{\mathrm{q}}$. When a very reactive substrate of high initial concentration $[\mathrm{S}]_{0}$ reacts with ${ }^{1} \mathrm{O}_{2}$ in $\mathrm{D}_{2} \mathrm{O}$ the process (2) becomes negligible 
([S $\left.]_{0}\left(k_{\mathrm{x}}+k_{\mathrm{r}}\right)>>k_{\mathrm{d}} \mathrm{D}_{2} \mathrm{O}\right)$ and the first term of eq (5) gets much smaller than the second one. Under these conditions, $k_{\mathrm{r}} /\left(k_{\mathrm{r}}+k_{\mathrm{q}}\right)$ can be calculated according to eq (6).

$$
\frac{k_{\mathrm{r}}}{k_{\mathrm{r}}+k_{\mathrm{q}}}=\frac{[\mathrm{S}]_{0}-[\mathrm{S}]}{\left[{ }^{1} \mathrm{O}_{2}\right]_{\text {cum }}}
$$

If, however, the same substrate of low initial concentration $\left[\mathrm{S}_{0}\right.$ reacts with ${ }^{1} \mathrm{O}_{2}$ in $\mathrm{H}_{2} \mathrm{O}$ the second term of eq (5) gets much smaller than the first one because quenching of ${ }^{1} \mathrm{O}_{2}$ occurs mainly through process (2) $\left([\mathrm{S}]_{0}\left(k_{\mathrm{r}}+k_{\mathrm{q}}\right)<<k_{\mathrm{d}}^{\mathrm{H} 2 \mathrm{O}}\right)$. Then, the rate constant for chemical quenching, $k_{\mathrm{r}}$, can be assessed by eq (7).

$$
k_{\mathrm{r}}=\frac{k_{\mathrm{d}}}{\left[{ }^{1} \mathrm{O}_{2}\right]_{\text {cum }}} \ln \frac{[\mathrm{S}]_{0}}{[\mathrm{~S}]}
$$

Thus, by taking advantage of the strong H-D isotopic effect on $k_{\mathrm{d}}$ and by using properly defined substrate concentrations, it is possible to determine $k_{\mathrm{r}}$ and $k_{\mathrm{r}} k_{\mathrm{r}}+k_{\mathrm{q}}$ and hence $k_{\mathrm{r}}+k_{\mathrm{q}}$ by the same experimental procedure. Of course, the accuracy is based on the validity of the assumption that the value of $k_{\mathrm{r}}$ is the same in $\mathrm{H}_{2} \mathrm{O}$ and $\mathrm{D}_{2} \mathrm{O}$. In fact, weak isotopic exchange with the solvent has been shown to slightly affect the rate constant (the rate constant is 1.4 to 1.5 times smaller in $\mathrm{CD}_{3} \mathrm{OD}$ than in $\mathrm{CH}_{3} \mathrm{OH}$ ) of the chemical reaction towards singlet oxygen through deuteration of the labile hydrogen of phenols. ${ }^{22}$

\section{Chemical generation of ${ }^{1} \mathrm{O}_{2}$ by thermolysis of $\mathrm{NDPO}_{2}$}

The water-soluble naphthalenic endoperoxide $\mathrm{NDPO}_{2}{ }^{34}$, prepared from the commercially available NDP (Synchem OHG), was used as a source of ${ }^{1} \mathrm{O}_{2}$. It is able to generate a welldefined amount of ${ }^{1} \mathrm{O}_{2}$, free from any other reactive species in a wide range of $\mathrm{pH}(5-11)$. Thermolysis of $\mathrm{NDPO}_{2}$ at $37{ }^{\circ} \mathrm{C}$ gives back the parent compound NDP and oxygen, $50 \%$ of which is in the singlet state (eq. 8)..$^{35-36}$

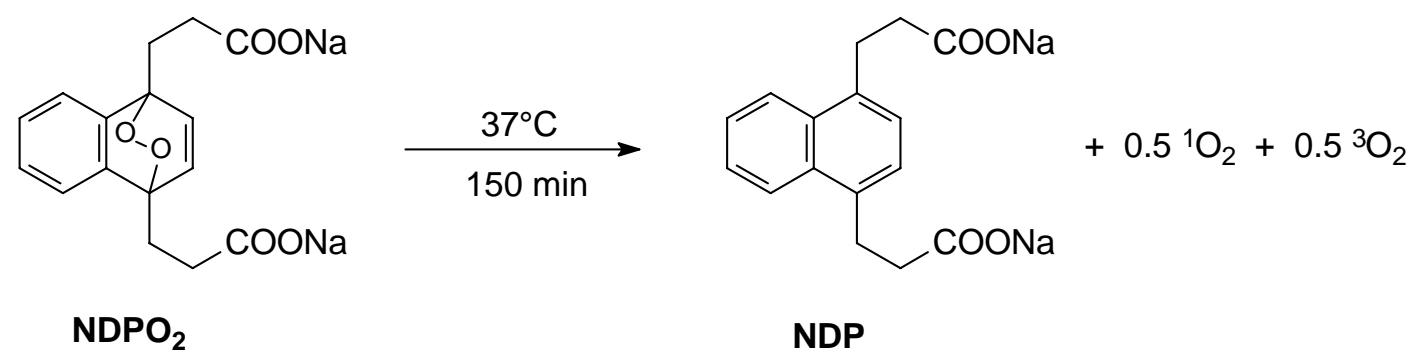

The thermolysis proceeds according to a first order kinetics with a half-time of decomposition of $23 \mathrm{~min}$ at $37^{\circ} \mathrm{C}$. Therefore, it may be calculated that $150 \mathrm{~min}$ are sufficient to release more than $99 \%$ of the trapped ${ }^{1} \mathrm{O}_{2}$. The amount of ${ }^{1} \mathrm{O}_{2}$ released can thus be assessed by UV-spectrophotometry by monitoring the increase of NDP at $290 \mathrm{~nm}$ (Figure 1). Due to the low rate constant between ${ }^{1} \mathrm{O}_{2}$ and $\operatorname{NDP}\left(k_{\mathrm{r}}+k_{\mathrm{q}}=2.8 \times 10^{6} \mathrm{M}^{-1} \mathrm{~s}^{-1}\right)^{35}$, it is possible to find concentrations of $\mathrm{NDPO}_{2}$ for which reversed reaction (8) can be negligible and for which Eq. (5) is validated. 


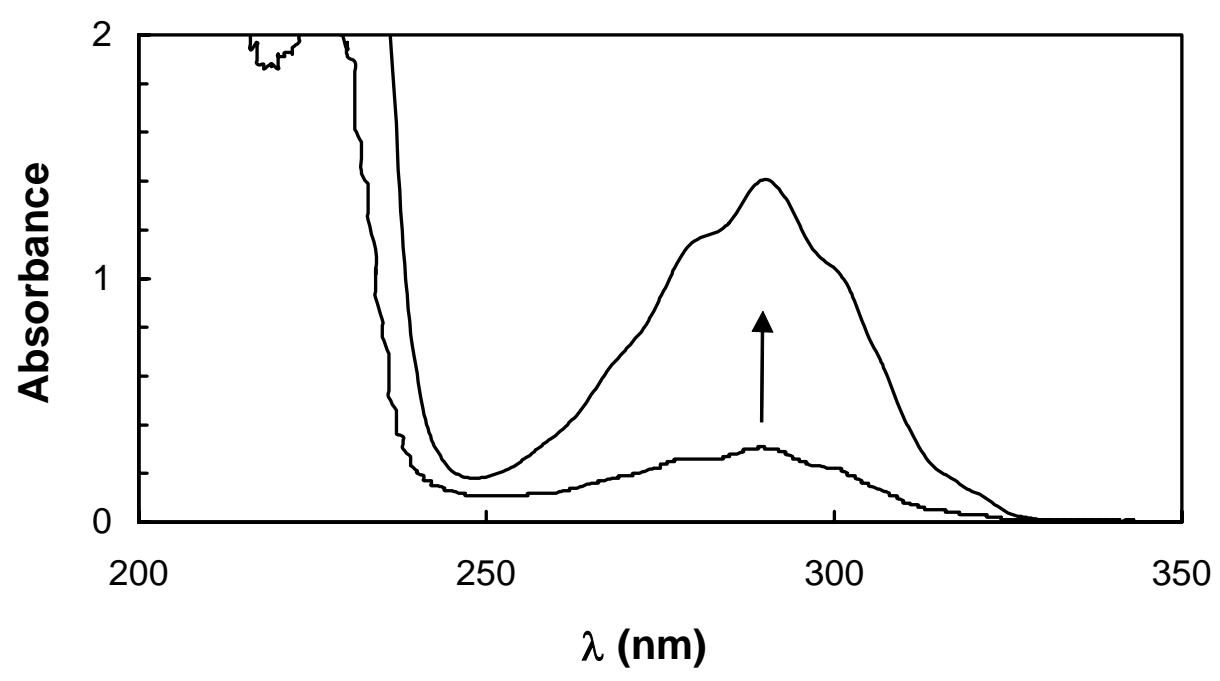

Figure 1. Formation of NDP by thermolysis of $\mathrm{NDPO}_{2}$ at $37^{\circ} \mathrm{C}$.

\section{Limits of the method}

Two kinetic requirements must be fulfilled for the determination of $\left(k_{\mathrm{r}}+k_{\mathrm{q}}\right)$ and $k_{\mathrm{r}}$ by this method. The first one depends on the relative concentrations of $\mathrm{NDPO}_{2}$, and $\mathrm{S}$. The concentration of $\mathrm{S}$ must be sufficient to avoid a significant quenching of ${ }^{1} \mathrm{O}_{2}$ by NDP formed during thermolysis (eq. 8). This condition is expressed by relation (9) where the superscripts $S$ and NDP refer to the quenching rate constants of S and NDP, respectively.

$$
[\mathrm{S}]_{0}\left(k_{\mathrm{r}}+k_{\mathrm{q}}\right)^{\mathrm{S}}>>[\mathrm{NDP}]\left(k_{\mathrm{r}}+k_{\mathrm{q}}\right)^{\mathrm{NDP}}
$$

As [NDP] is always lower than $\left[\mathrm{NDPO}_{2}\right]_{0}$, the inequality (9) leads to a first condition with regard to the maximum amount of $\mathrm{NDPO}_{2}$ that may be used.

$$
\left[\mathrm{NDPO}_{2}\right]_{0}{ }^{\max }<<[\mathrm{S}]_{0} \frac{\left(k_{\mathrm{r}}+k_{\mathrm{q}}\right)^{\mathrm{S}}}{\left(k_{\mathrm{r}}+k_{\mathrm{q}}\right)^{\mathrm{NDP}}}
$$

The second kinetic requirement concerns the ratio of substrate consumed according to eq. 4. It must be higher than $5 \%\left([\mathrm{~S}]<0.95[\mathrm{~S}]_{0}\right)$ for an accurate determination by UV-visible spectrometry or by HPLC. Since half of the oxygen released during thermolysis is in the singlet state $\left(\left[{ }^{1} \mathrm{O}_{2}\right]_{\mathrm{cum}}=0.5\left[\mathrm{NDPO}_{2}\right]_{0}\right)$, the minimum concentration of endoperoxide $\left[\mathrm{NDPO}_{2}\right]_{0}{ }^{\min }$ may be inferred from eq. (6) as

$$
0.5\left[\mathrm{NDPO}_{2}\right]_{0}{ }^{\min } \geq 0.05[\mathrm{~S}]_{0} \frac{\left(k_{\mathrm{r}}+k_{\mathrm{q}}\right)^{\mathrm{S}}}{k_{\mathrm{r}}^{\mathrm{s}}}
$$

Equations (10) and (11) lead to the double inequality (12) which simplifies to (13) by dropping the terms $\left[\mathrm{NDPO}_{2}\right]_{0}$ and $[\mathrm{S}]_{0}$. 


$$
\begin{gathered}
0.1[\mathrm{~S}]_{0} \frac{\left(k_{\mathrm{r}}+k_{\mathrm{q}}\right)^{\mathrm{S}}}{k_{\mathrm{r}}^{\mathrm{S}}} \leq\left[\mathrm{NDPO}_{2}\right]_{0}<[\mathrm{S}]_{0} \frac{\left(k_{\mathrm{r}}+k_{\mathrm{q}}\right)^{\mathrm{S}}}{\left(k_{\mathrm{r}}+k_{\mathrm{q}}\right)^{\mathrm{NDP}}} \\
0.1 \frac{\left(k_{\mathrm{r}}+k_{\mathrm{q}}\right)^{\mathrm{S}}}{k_{\mathrm{r}}^{\mathrm{S}}}<\frac{\left(k_{\mathrm{r}}+k_{\mathrm{q}}\right)^{\mathrm{S}}}{\left(k_{\mathrm{r}}+k_{\mathrm{q}}\right)^{\mathrm{NDP}}}
\end{gathered}
$$

The inequality (13) will be satisfied if $\left(k_{\mathrm{r}}+k_{\mathrm{q}}\right)^{\mathrm{S}} /\left(k_{\mathrm{r}}+k_{\mathrm{q}}\right)^{\mathrm{NDP}}$ is at least 10 times higher than $0.1\left(k_{\mathrm{r}}+k_{\mathrm{q}}\right)^{\mathrm{S}} / k_{\mathrm{r}}^{\mathrm{S}}$. Therefore we obtain (14).

$$
\frac{\left(k_{\mathrm{r}}+k_{\mathrm{q}}\right)^{\mathrm{S}}}{k_{\mathrm{r}}^{\mathrm{S}}} \leq \frac{\left(k_{\mathrm{r}}+k_{\mathrm{q}}\right)^{\mathrm{S}}}{\left(k_{\mathrm{r}}+k_{\mathrm{q}}\right)^{\mathrm{NDP}}}
$$

which implies that the chemical rate constant of $S$ should be higher or equal to the overall rate constant of NDP:

$$
k_{\mathrm{r}}^{\mathrm{S}} \geq\left(k_{\mathrm{r}}+k_{\mathrm{q}}\right)^{\mathrm{NDP}}
$$

Despite its simplicity, this condition is of little practical use since the absolute value of $k_{\mathrm{r}}{ }^{\mathrm{S}}$ is not known and because it is impossible to predict it from the chemical formula of $\mathrm{S}$.

However, this inequality can be graphically expressed in Figure 2. Substituting $\left(k_{\mathrm{r}}+k_{\mathrm{q}}\right)^{\mathrm{S}}$ by $10^{\log \left(k_{\mathrm{r}}+k_{\mathrm{q}}\right)^{\mathrm{S}}}$ in eq. (14) and $\left(k_{\mathrm{r}}+k_{\mathrm{q}}\right)^{\mathrm{NDP}}$ by its known value $2.8 \times 10^{6} \mathrm{M}^{-1} \mathrm{~s}^{-1} 35$ one obtains:

$$
\frac{k_{\mathrm{r}}^{\mathrm{S}}}{\left(k_{\mathrm{r}}+k_{\mathrm{q}}\right)^{\mathrm{S}}} \geq 2.8 \times 10^{6} \times 10^{-\log \left(k_{\mathrm{r}}+k_{\mathrm{q}}\right)^{\mathrm{S}}}
$$

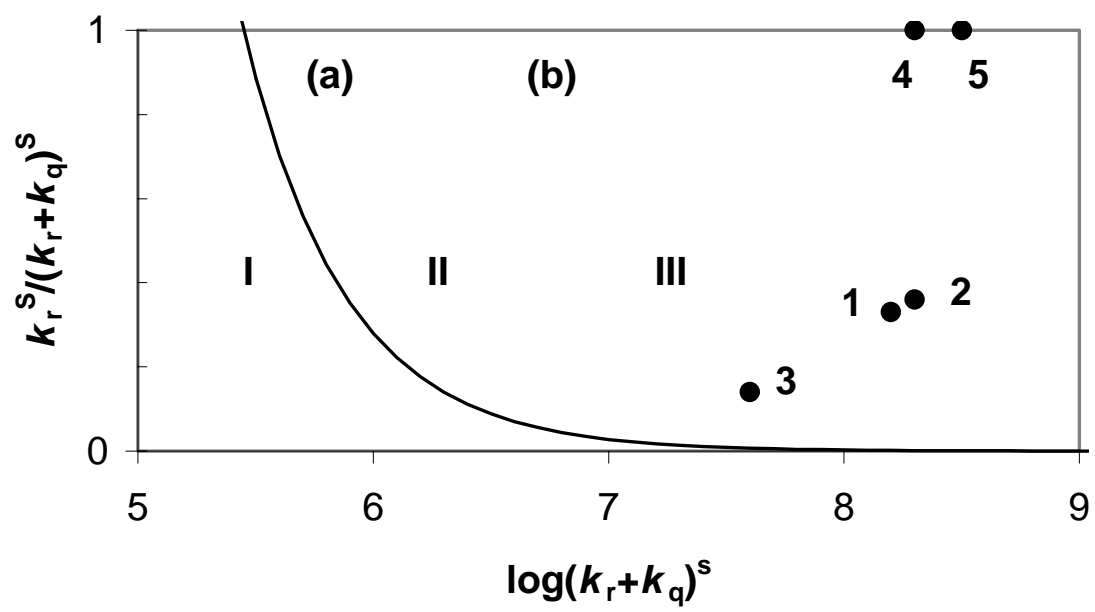

Figure 2. Plots of $k_{\mathrm{r}}^{\mathrm{S}} /\left(k_{\mathrm{r}}+k_{\mathrm{q}}\right)^{\mathrm{S}}$ versus $\log \left(k_{\mathrm{r}}+k_{\mathrm{q}}\right)^{\mathrm{S}}$ showing the areas where the method is applicable (III), risky (II) or useless (I) and positions of the substrates 1-5.

Figure 2 plots $k_{\mathrm{r}}^{\mathrm{S}} /\left(k_{\mathrm{r}}+k_{\mathrm{q}}\right)^{\mathrm{S}} v \mathrm{~s}$. $\log \left(k_{\mathrm{r}}+k_{\mathrm{q}}\right)^{\mathrm{S}}$. The overall area of Fig. 2 is divided in three parts by two curves calculated as $k_{\mathrm{r}}^{\mathrm{S}} /\left(k_{\mathrm{r}}+k_{\mathrm{q}}\right)^{\mathrm{S}}=2.8 \times 10^{6} \times 10^{-\log \left(k_{\mathrm{r}}+k_{\mathrm{q}}\right)^{\mathrm{S}}}$ (a) and $k_{\mathrm{r}}^{\mathrm{S}} /\left(k_{\mathrm{r}}+k_{\mathrm{q}}\right)^{\mathrm{S}}=2.8 \times$ $10^{5} \times 10^{-\log \left(k_{\mathrm{r}}+k_{\mathrm{q}}\right)^{\mathrm{S}}}$ (b). Part I corresponds to substrates for which the inequality (16) is not 
fulfilled. In this area, the method is not applicable since the substrates are not reactive enough towards ${ }^{1} \mathrm{O}_{2}$. Part III is the location of substrates for which inequality (16) is fulfilled. This is the area, where highly reactive substrates may be studied according to the method presented here. In the intermediate area II, the technique is still usable but quenching by NDP is no more negligible and the values of $k_{\mathrm{r}}{ }^{\mathrm{S}}$ and of $k_{\mathrm{q}}^{\mathrm{S}}$ are less reliable.

Finally, the inequalities (10) and (11) also lead to constraints on the minimum $\left(\left[\mathrm{NDPO}_{2}\right]_{0}{ }^{\mathrm{min}}\right.$ ) and maximum $\left(\left[\mathrm{NDPO}_{2}\right]_{0}{ }^{\mathrm{max}}\right.$ ) concentrations of $\mathrm{NDPO}_{2}$ required, respectively. In order to make the choice of appropriate experimental conditions easier, the recommended concentrations of substrate and of endoperoxide have been reported in table 1 as a function of the substrate reactivity.

Table 1. Lower and upper limits of initial concentrations of substrate $[\mathrm{S}]_{0}$ and endoperoxide $\left[\mathrm{NDPO}_{2}\right]_{0}$ recommended for substrates of variable reactivity

\begin{tabular}{|c|c|c|c|c|c|c|c|c|c|}
\hline \multirow{2}{*}{$\begin{array}{c}\log \left(k_{\mathrm{r}}+k_{\mathrm{q}}\right)^{\mathrm{S}} \\
k_{\mathrm{r}}^{\mathrm{S}} /\left(k_{\mathrm{r}}+k_{\mathrm{q}}\right)^{\mathrm{S}}\end{array}$} & \multicolumn{3}{|c|}{7} & \multicolumn{3}{|c|}{8} & \multicolumn{3}{|c|}{9} \\
\hline & 0.01 & 0.1 & 1 & 0.01 & 0.1 & 1 & 0.01 & 0.1 & 1 \\
\hline$\left[\mathrm{NDPO}_{2}\right]_{0} /[\mathrm{S}]_{0} \geq$ & 10 & 1 & 0.1 & 10 & 1 & 0.1 & 10 & 1 & 0.1 \\
\hline$\left[\mathrm{NDPO}_{2}\right]_{0} /[\mathrm{S}]_{0} \leq$ & 3.6 & 3.6 & 3.6 & 36 & 36 & 36 & 360 & 360 & 360 \\
\hline$[\mathrm{S}]_{0} \mathrm{H}_{2} \mathrm{O} /(\mathrm{mM})<<$ & 32 & 32 & 32 & 3.2 & 3.2 & 3.2 & 0.32 & 0.32 & 0.32 \\
\hline$[\mathrm{S}]_{0}^{\mathrm{D}_{2} \mathrm{O}} /(\mathrm{mM})>>$ & 1.5 & 1.5 & 1.5 & 0.15 & 0.15 & 0.15 & 0.015 & 0.015 & 0.015 \\
\hline
\end{tabular}

\section{Choice of the substrate and determination of rate constants, $\boldsymbol{k}_{\mathbf{r}}$ and $\boldsymbol{k}_{\mathrm{q}}$}

To exemplify our method, the anthraquinonic dye, carminic acid 1, was chosen as a substrate. This compound can be used as an indicator for the determination of traces of cobalt, ${ }^{37}$ iron, ${ }^{38}$ nitrite $^{39}$ and osmium ${ }^{40}$ but it is mainly used as a coloring agent ${ }^{41}$ and as an antioxidant ingredient in foodstuffs, pharmaceuticals and cosmetics. ${ }^{42-43}$ Moreover, it exhibits a characteristic absorption at $530 \mathrm{~nm}$ which disappears by reaction with ${ }^{1} \mathrm{O}_{2}$ allowing its monitoring by vis absorption spectrometry (Figure 3) since neither NDP nor $\mathrm{NDPO}_{2}$ absorb light above $350 \mathrm{~nm}$ (Figure 1).

Aqueous $\left(\mathrm{H}_{2} \mathrm{O}\right.$ or $\left.\mathrm{D}_{2} \mathrm{O}\right)$ phosphate buffered ( $\mathrm{pH}$ 6.8) solutions of $\mathrm{NDPO}_{2}$ and carminic acid were maintained at $37{ }^{\circ} \mathrm{C}$ for 3 hours. The reaction of carminic acid with the chemically generated ${ }^{1} \mathrm{O}_{2}$ was monitored at $537 \mathrm{~nm}$ (Figure 3). 


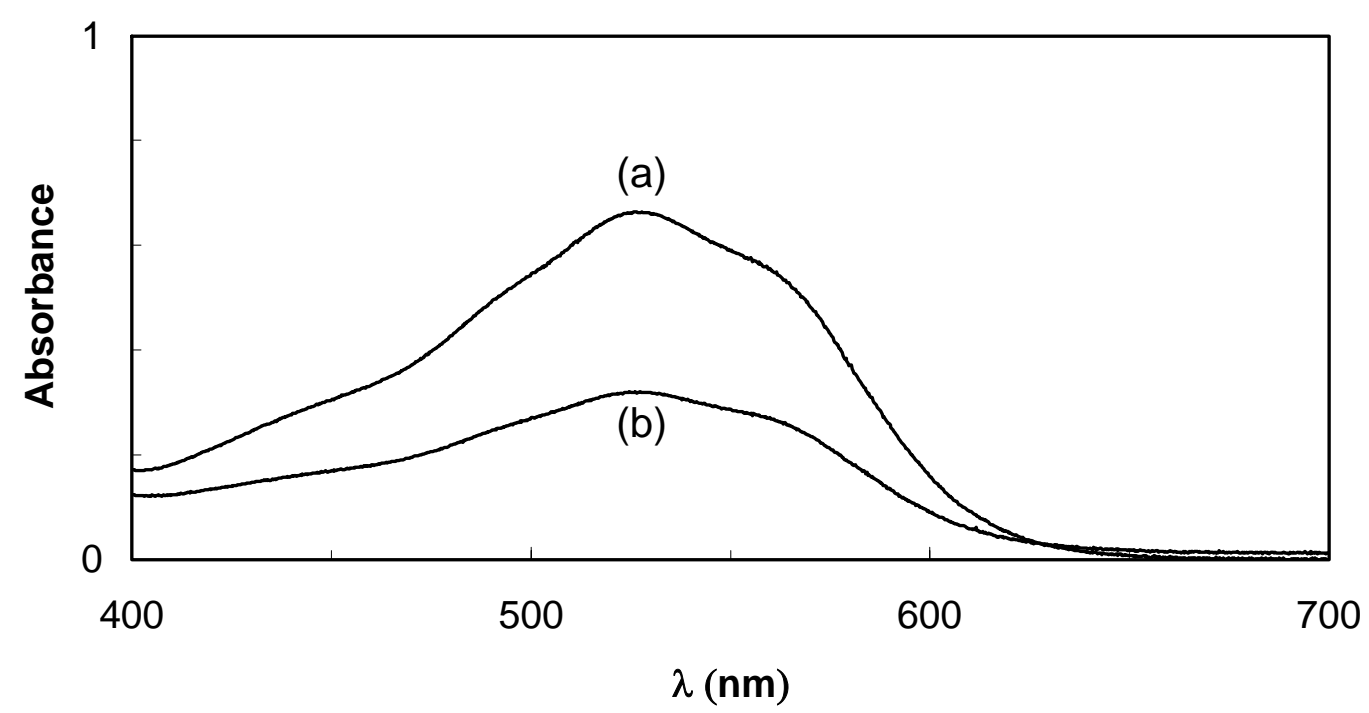

Figure 3. Visible spectra of solutions of carminic acid $(0.077 \mathrm{mM})$ in $\mathrm{H}_{2} \mathrm{O}$ after warming for $3 \mathrm{~h}$ at $37^{\circ} \mathrm{C}$ with $\left[\mathrm{NDPO}_{2}\right]=0 \mathrm{mM}$ (a) or $2.48 \mathrm{mM}$ (b).

By applying relations (6) or (7) to the experimental results reported in Table 2, the values of the chemical $\left(k_{\mathrm{r}}\right)$ and of the overall $\left(k_{\mathrm{r}}+k_{\mathrm{q}}\right)$ rate constants were assessed to $1.5 \times 10^{8} \mathrm{M}^{-1} \mathrm{~s}^{-1}$ and $4.5 \times 10^{8} \mathrm{M}^{-1} \mathrm{~s}^{-1}$ respectively. Thus, carminic acid is highly reactive towards ${ }^{1} \mathrm{O}_{2}$ but only $33 \%$ of the interacting ${ }^{1} \mathrm{O}_{2}$ induces the irreversible oxidation of the substrate.

In order to confirm the value found for $\left(k_{\mathrm{r}}+k_{\mathrm{q}}\right)$ we resorted to flash photolysis which allows a direct measurement of this overall rate constant. A rough estimation of $\left(k_{\mathrm{r}}+k_{\mathrm{q}}\right)=2.1 \times 10^{8} \mathrm{M}^{-1}$ $\mathrm{s}^{-1}$ was obtained in $\mathrm{D}_{2} \mathrm{O}$ at $\mathrm{pH}=7.5$ using tetrasodium tetrakis(sulfonatophenyl) porphyrin as a sensitizer of ${ }^{1} \mathrm{O}_{2} \cdot{ }^{44}$ This rate constant could not be determined very accurately by this photopphysical method because the screening effect of carminic acid on the absorbance of the photosensitizer restricted the practical range of substrate concentration. Keeping in mind this problem, we may consider that the values obtained by both methods are in reasonably good agreement.

Table 2. Calculation of the chemical $\left(k_{\mathrm{r}}\right)$ and overall $\left(k_{\mathrm{r}}+k_{\mathrm{q}}\right)$ rate constants of quenching of singlet oxygen for carminic acid in water at $\mathrm{pH}=6.8$

\begin{tabular}{cccccc}
\hline & \multicolumn{2}{c}{$\mathrm{H}_{2} \mathrm{O}^{(\mathrm{a})}$} & & \multicolumn{2}{c}{$\mathrm{D}_{2} \mathrm{O}^{(\mathrm{b})}$} \\
\cline { 2 - 3 } \cline { 5 - 6 }$\left[{ }^{1} \mathrm{O}_{2}\right]_{\text {cum }}(\mathrm{mM})$ & {$[\mathrm{S}] /[\mathrm{S}]_{0}$} & $k_{\mathrm{r}}\left(10^{8} \mathrm{M}^{-1} \mathrm{~s}^{-1}\right)^{\mathrm{c}}$ & & {$[\mathrm{S}]_{0}-[\mathrm{S}](\mathrm{mM})$} & $k_{\mathrm{r}} /\left(k_{\mathrm{r}}+k_{\mathrm{q}}\right)^{\mathrm{d}}$ \\
\hline 0.62 & 0.69 & 1.5 & & 0.21 & 0.32 \\
1.24 & 0.48 & 1.5 & & 0.40 & 0.33 \\
\hline
\end{tabular}

${ }^{(\mathrm{a})}[\mathrm{S}]_{0}=0.07 \mathrm{mM},{ }^{(\mathrm{b})}[\mathrm{S}]_{0}=0.7 \mathrm{mM},{ }^{(\mathrm{c})}$ eq $7,{ }^{(\mathrm{d})}$ eq 6. 
In order to show the value of the method, the reactivity of a series of well-known phenolic antioxidants 2-5 towards ${ }^{1} \mathrm{O}_{2}$ was determined. Due to the lack of screening effect for substrates 2-5, $k_{\mathrm{r}}+k_{\mathrm{q}}$ were determined by flash photolysis. Results are reported in Table 3 and in Figure 2. Taking into account the experimental errors, rate constants can be evaluated with $20 \%$ precision.

Table 3. Overall chemical rate constants $\left(k_{\mathrm{r}}+k_{\mathrm{q}}\right)$ and $\left(k_{\mathrm{r}} / k_{\mathrm{r}}+k_{\mathrm{q}}\right)$ determined for substituted phenols

\begin{tabular}{ccccccc}
\hline Entry & $\begin{array}{c}{\left[\mathrm{NDPO}_{2}\right]_{0}} \\
(\mathrm{mM})\end{array}$ & $\begin{array}{c}{[\mathrm{S}]_{0} \mathrm{H}_{2} \mathrm{O}} \\
(\mathrm{mM})\end{array}$ & $\begin{array}{c}{[\mathrm{S}]_{0}{ }^{\mathrm{D}_{2} \mathrm{O}}} \\
(\mathrm{mM})\end{array}$ & $\log \left(k_{\mathrm{r}}+k_{\mathrm{q}}\right)$ & $k_{\mathrm{r}} /\left(k_{\mathrm{r}}+k_{\mathrm{q}}\right)$ & analysis $^{\mathrm{c}}$ \\
\hline $\mathbf{1}$ & 2.5 & 0.07 & 0.7 & $8.2^{\mathrm{a}}$ & $0.33^{\mathrm{a}}$ & UV/vis \\
$\mathbf{2}$ & 2.3 & 0.1 & 1.3 & $8.3^{\mathrm{b}}$ & $0.36^{\mathrm{a}}$ & HPLC \\
$\mathbf{3}$ & 0.8 & 0.1 & 0.94 & $7.6^{\mathrm{b}}$ & $0.14^{\mathrm{a}}$ & HPLC \\
$\mathbf{4}$ & 2.3 & 0.1 & 1.2 & $8.3^{\mathrm{b}}$ & $1^{\mathrm{a}}$ & HPLC \\
$\mathbf{5}$ & 5.6 & 0.1 & 20 & $8.5^{\mathrm{b}}$ & $1^{\mathrm{a}}$ & NMR \\
\hline
\end{tabular}

a Determined by the method described in this paper. ${ }^{b}$ Determined by flash photolysis. ${ }^{\mathrm{c}}$ Analytical method used to measure [S].

In the case of substrate complete unknown $\mathrm{S}$, we suggest to work first in $\mathrm{D}_{2} \mathrm{O}$ with a relatively high concentration of $\mathrm{S}(10 \mathrm{mM})$ and with three concentrations of $\mathrm{NDPO}_{2}(1,10$ and $100 \mathrm{mM}$ ) to see if the reactivity of the substrate is high enough for our method. A first estimation of $k_{\mathrm{r}}^{\mathrm{S}} /\left(k_{\mathrm{r}}+k_{\mathrm{q}}\right)^{\mathrm{S}}$ should be obtained. In a second step, lower concentration of S (1 mM) can be tested with $\mathrm{NDPO}_{2}$ concentrations $(1,10$ and $100 \mathrm{mM})$, if necessary a supplementary dilution of $\mathrm{S}$ and $\mathrm{NDPO}_{2}$ can be used to obtained $k_{\mathrm{r}}^{\mathrm{S}}$ and thus $\left(k_{\mathrm{r}}+k_{\mathrm{q}}\right)^{\mathrm{S}}$.

\section{Conclusions}

The method described in this paper for the determination of $k_{\mathrm{r}}$ and $\left(k_{\mathrm{r}}+k_{\mathrm{q}}\right)$ of water-soluble substrates is easy to implement. It is well adapted for all substrates for which $\left(k_{\mathrm{r}}+k_{\mathrm{q}}\right)$ is higher than $10^{7} \mathrm{M}^{-1} \mathrm{~s}^{-1}$. The UV/visible spectroscopy method is particularly convenient to monitor the concentration of substrates absorbing above $350 \mathrm{~nm}$, but for colorless molecules any other chromatographic or spectroscopic method can also be applied. The singlet oxygen source, $\mathrm{NDPO}_{2}$, could be obtained either by chemical or photochemical methods, from the commercially available NDP. In opaque media, this method could also be applied in contrast with methods based on photochemical generation of ${ }^{1} \mathrm{O}_{2}$.

The same principle can be applied to many other solvents provided that the difference of ${ }^{1} \mathrm{O}_{2}$ lifetime between the perdeuterated and the perhydrogenated forms of the solvent is large enough $\left(\mathrm{CH}_{3} \mathrm{OH}, \mathrm{CH}_{3} \mathrm{CN}, \mathrm{CH}_{3} \mathrm{COCH}_{3}, \mathrm{CHCl}_{3}\right)$. In this case a lipophilic naphthalenic compound such as 1,4-dimethylnaphthalene is used instead of NDP. 


\section{Experimental Section}

General Procedures. Carminic acid, methyl gallate, caffeic acid, trimethylhydroquinone, trolox and tetrasodium tetrakis(sulfonatophenyl) porphyrin (Aldrich) were used without further purification. NDP can be purchased from Synchem OHG or synthetized from 1,4dimethylnaphthalene. ${ }^{36}$

UV-VIS absorption spectra were recorded on a Varian CARY 50 spectrophotometer.

HPLC was performed using a Waters 600 controller pumps, a Water 490E detector and a NovaPak C18 $4 \mu \mathrm{m} 4.6 \times 250 \mathrm{~mm}$ cartridge at a flow rate of $0.7 \mathrm{~mL} / \mathrm{min}$ with a mixture wateracetonitrile or water-methanol.

${ }^{1} \mathrm{H}$ NMR spectra were recorded at $200 \mathrm{MHz}$ on a Bruker AC-200.

Endoperoxide of disodium 3,3'-(naphthalene-1,4-diyl)dipropionate $\left(\mathrm{NDPO}_{2}\right)$ was prepared as described. $^{36}$ 3,3'-(Naphthalene-1,4-diyl)dipropionic acid (2 g, $7.3 \mathrm{mmol}, 0.37 \mathrm{M}$ ) was dissolved in $20 \mathrm{~mL}$ of an aqueous solution of sodium hydroxide $(0.59 \mathrm{~g}, 14.7 \mathrm{mmol})$, sodium hydrogen carbonate $(0.2 \mathrm{~g}, 2.4 \mathrm{mmol})$, sodium carbonate $(0.5 \mathrm{~g}, 4.7 \mathrm{mmol})$ and sodium molybdate dihydrate (2.5 g, $10.3 \mathrm{mmol}, 0.51 \mathrm{M}$ ). The solution was immersed in a thermostated bath maintained at $20^{\circ} \mathrm{C}$. Six fractions of $2 \mathrm{~mL}(20 \mathrm{mmol})$ of hydrogen peroxide were added within $90 \mathrm{~min}$. The mixture was cooled to $0^{\circ} \mathrm{C}$ with an ice bath and was acidified under stirring at $\mathrm{pH}=$ 2.5 with cold phosphoric acid ( $2 \mathrm{M})(25 \mathrm{~mL}, 50 \mathrm{mmol})$. The white precipitate was collected on a sintered glass funnel and washed three times with iced water. The moist acid was dissolved in $300 \mathrm{~mL}$ of cold THF $\left({ }^{\circ} \mathrm{C}\right)$ and dried with $15 \mathrm{~g}$ of $\mathrm{MgSO}_{4}$. After filtration, $7 \mathrm{~mL}(14 \mathrm{mmol})$ of 2 $\mathrm{M}$ sodium methylate in methanol were added, and the precipitate was collected by centrifugation, washed with cold ether, and dried $30 \mathrm{~min}$ in vacuum $\left(0.1\right.$ Torr, $\left.0{ }^{\circ} \mathrm{C}\right)$, yielding endoperoxide (2.34 g, 92\%) as a white powder.

Determination of the ${ }^{1} \mathrm{O}_{2}$ chemical rate constant $\left(k_{\mathrm{r}}\right)$ for carminic acid. $250 \mu \mathrm{L}$ of a solution of carminic acid $(7.7 \mathrm{mM})$ in $\mathrm{D}_{2} \mathrm{O}$ was added to 50 or $100 \mu \mathrm{L}$ of $\mathrm{NDPO}_{2}(0.088 \mathrm{M})$ in $\mathrm{D}_{2} \mathrm{O}$. The final volume was adjusted to $2.75 \mathrm{~mL}$ by means of phosphate buffer $\left(10^{-2} \mathrm{M}\right)$ in $\mathrm{D}_{2} \mathrm{O}(\mathrm{pD}=6.8)$. The solution was maintained at $37^{\circ} \mathrm{C}$ for 3 hours and the absorbance was measured at $527 \mathrm{~nm}$ after dilution (1/10). $k_{\mathrm{r}}$ can be calculated from eq. (7).

Determination of the ${ }^{1} \mathrm{O}_{2}$ overall rate constant $\left(k_{\mathrm{r}}+k_{\mathrm{q}}\right)$ for carminic acid. $25 \mu \mathrm{L}$ of a solution of carminic acid $(7.7 \mathrm{mM})$ in $\mathrm{D}_{2} \mathrm{O}$ was added to 50 or $100 \mu \mathrm{L}$ of $\mathrm{NDPO}_{2}(0.088 \mathrm{M})$ in $\mathrm{D}_{2} \mathrm{O}$. The final volume was adjusted to $2.75 \mathrm{~mL}$ by means of phosphate buffer $\left(10^{-2} \mathrm{M}\right)$ in $\mathrm{D}_{2} \mathrm{O}(\mathrm{pD}=6.8)$. The solution was maintained at $37^{\circ} \mathrm{C}$ for 3 hours and the absorbance was measured at $527 \mathrm{~nm}$. $k_{\mathrm{r}}$ $+k_{\mathrm{q}}$ can be calculated from eq. (6) using $k_{\mathrm{r}}$ from eq. (7).

${ }^{1} \mathrm{O}_{2}$ overall rate constants $\left(k_{\mathrm{r}}+k_{\mathrm{q}}\right)$ for compounds 2-5 were measured by flash photolysis by using a system already described in detail. ${ }^{44,45}$ 


\section{References}

1. Bissonnette, R.; Tremblay, J. F.; Juzenas, P.; Boushira, M.; Lui, H. J. Invest. Dermatol. 2002, 119, 77.

2. $\quad$ Wang, J.; Xing, D.; He, Y.; Hu, X. FEBS Letters 2002, 523,128.

3. Niedre, M.; Patterson, M. S.; Wilson, B .C. Photochem. Photobiol. 2002, 75, 382.

4. Luna, M. C.; Chen, X.; Wong, S.; Tsui, J.; Rucker, N.; Lee A. S.; Gomer, C. Cancer Research 2002, 62, 1458.

5. Wasserman, H.; Murray, R. W. In Organic Chemistry: Singlet Oxygen; Academic Press: New York, 1979; Vol. 40.

6. Ranby, B.; Rabeck, J. F. In Singlet Oxygen Reactions with Organic Compounds and Polymers., Wiley: New York, 1978.

7. Dam, N.; Scurlock, R. D.; Wang, B.; Ma, L.; Sundahl, M.; Ogilby, P. R. Chem. Mater. 1999, $11,1302$.

8. Ogilby, P. R.; Kristiansen, M.; Martire, D. O.; Scurlock, R. D.; Taylor, V. L.; Clough, R. L. Adv. Chem. Ser. 1996, 249, 113.

9. Scurlock, R. D.; Wang, B.; Ogilby, P. R.; Sheats, J. R.; Clough, R. L. J. Am. Chem. Soc. 1995, 117, 10194.

10. Tanielian, C.; Mechin, R.; Shakirullah, M. J. Photochem. Photobiol. A: Chem. 1992, 64, 191.

11. Schweitzer, C.; Schmidt, R. Chem. Rev. 2003, 103, 1685.

12. Wilkinson, F.; Helman, W. P.; Ross, A. B. J. Phys. Chem. Ref. Data 1995, 24, 663.

13. Bonesi, M.; Fagnoni, M.; Albini, A. J. Org. Chem. 2004, 69, 928.

14. Wilkinson, F. Pure Appl. Chem. 1997, 69, 851.

15. Silva, E.; Jopia, M.; Edwards, A. M.; Lemp, E.; De la Fuente, J. R. ; Lissi, E. Photochem. Photobiol. 2002, 75, 585.

16. Evans, D. F.; Tucker, J. N. J. Chem. Soc., Faraday Trans. 2 1976, 72, 1661.

17. Montenegro, M. A.; Nazareno, N. A.; Durantini, E. N.; Borsarelli, C. D. Photochem. Photobiol. 2002, 75, 353.

18. Briviba, K.; Sies, H. Methods Enzymol. 2000, 319, 222.

19. Gorman, A. A.; Rodgers, M. J. Photochem; Photobiol. B: Biol. 1992, 14, 159.

20. Oliveros, E.; Besançon, F.; Boneva, M.; Kräutler, B.; Braun, A. M. J. Photochem. Photobiol. B: Biol. 1995, 29, 37.

21. Tournaire, C.; Croux, S.; Maurette, M.T.; Beck, I.; Hocquaux, M.; Braun, A. M.; Oliveros, E. J. Photochem; Photobiol. B: Biol. 1993, 19, 205.

22. Tournaire, C.; Croux, S.; Maurette, M. T. ; Braun, A. M., Oliveiros E. New J. Chem. 1991, 15, 909.

23. Gunther, G.; Lemp, E.; Zanocco, A. L. J. Photochem. Photobiol. A: Chem 2002, 151, 1.

24. Galliani, G.; Manitto, P.; Monti, D. Isr. J. Chem. 1983, 23, 219.

25. Speranza, G.; Manitto, P.; Monti, D. J. Photochem. Photobiol. B: Biol. 1990, 8, 51. 
26. Manitto, P.; Speranza, G.; Monti, D.; Gramatica, P. Tetrahedron Lett. 1987, 28, 4221.

27. Baltschun, D.; Beutner, S.; Briviba, K.; Martin, H. D.; Paust, J.; Peters, M.; Rover, S.; Sies, H.; Stahl, W.; Steigel, A.; Stenhorst, F. Liebigs Ann./Recueil 1997, 9, 1887.

28. Di Mascio, P.; Sies, H. J. Am. Chem. Soc. 1989, 111, 2909.

29. Kaiser, S.; Di Mascio, P.; Murphy, M .E.; Sies, H. Arch. Biochem. Biophys. 1990, 277, 101.

30. Devasagayam, T. P. A.; Sundquist, A. R.; Di Mascio, P.; Kaiser, S.; Sies, H. J. Photochem. Photobiol. B: Biol. 1991, 9, 105.

31. Lutgerink, J. T.; Van den Akker, E.; Smeets, I.; Pachen, D.; Van Dijk, P.; Aubry, J. M.; Joenje, H.; Lafleur, M.; Vincent, M.; Retel, J. Mutation Res. 1992, 275, 377.

32. Pierlot, C.; Aubry, J. M.; Briviba, K.; Sies, H.; Di Mascio, P. Methods Enzymol. 2000, 319, 3.

33. Pellieux, C.; Dewilde, A.; Pierlot, C.; Aubry, J. M. Methods Enzymol. 2000, 319, 197.

34. Aubry, J. M.; Cazin, B.; Duprat, F. J. Org. Chem. 1989, 4,726.

35. Martinez, G. R.; Ravanat, J. L. ; Medeiros, M. H. G. ; Cadet, J. ; Di Mascio, P. J. Am. Chem. Soc. 2000, 122, 10212.

36. Aubry, J. M.; Pierlot, C.; Rigaudy, J.; Schmidt, R. Acc. Chem. Res. 2003, 36, 668.

37. Zhang, Z.; Zhang, G. Fenxi Huaxue 1990, 18, 929.

38. Pecev, T. G.; Mitic, S. S. J. Serb. Chem. Soc. 1994, 59, 195.

39. Manzoori, J. L.; Sorouraddin, M. H.; Haji-Shabani, A. M Talanta 1998, 46, 1379.

40. Manzoori, J. L.; Sorouraddin, M. H.; Amjadi, M. Talanta 2000, 53, 61.

41. Panadero, S.; Gomez-Henz, A.; Pérez-Bedito, D. Fresenius J. Anal. Chem. 1997, 357, 80.

42. Oberthur, W.; Kesel, A. J. Antioxidative vitamin B6 analogs, patent WO 2000066599 (2000) $68 \mathrm{pp}$.

43. Balavoine, G. G. A.; Geletii, Y. V. Nitric Oxide 1999, 3, 40.

44. Nahor, G. S.; Rabani, J.; Grieser, F. J. Phys. Chem. 1981, 85, 697.

45. Shafii, F.; Schmidt, R. J. Phys. Chem. A. 2001, 105, 1805. 